\title{
Protein Methylation
}

National Cancer Institute

\section{Source}

National Cancer Institute. Protein Methylation. NCI Thesaurus. Code C21035.

Post-translational enzymatic covalent addition of a methyl group(s) to a peptide or protein. 